\title{
Jonglei Canal Project Under Potential Developments in the Upper Nile States
}

\author{
Mariam M. Allam, ${ }^{1,2}$ Hesham M. Bekhit, ${ }^{1}$ Alaa M. Elzawahry ${ }^{1}$ and Mohamed N. Allam ${ }^{1}$ \\ ${ }^{1}$ Cairo University, Cairo, Egypt; ${ }^{2}$ Massachusetts Institute of Technology, Cambridge, Massachusetts.
}

\begin{abstract}
Nile basin countries are experiencing water scarcity due to rapid growth in population and climate change. This scarcity drew attention to the vast amount of water lost in the swamp areas of the Nile basin. Preventing this water loss is essential for reducing the food gap and promoting development in all Nile countries. Jonglei Canal is an important project that was proposed to reduce the vast water losses in the Sudd region in Southern Sudan. The Jonglei Canal project was launched and stopped in the 1980s due to civil war in Sudan. Recently Upper Nile riparian countries have published their plans for possible development projects which might significantly reduce flow to the Sudd region and hence reduce the potential water savings from Jonglei Canal. In addition, environmental concerns about the Jonglei Canal project have been raised by local tribes, that the project may reduce the size of swamps and adversely affect their grazing activities. This paper investigates the impact on the feasibility of the Jonglei Canal project of the proposed development projects in the upstream countries. The projected size of the swamp area is quantified under different scenarios of upstream development and Jonglei Canal operation. The Nile decision support tool (Nile DST model) and a HEC-RAS model were used for hydrologic and hydraulic simulations of the White Nile system. It was found that the ambitious expansion of irrigation projects may affect the benefits of the Jonglei Canal project. The hydraulic simulations indicated that the reduction in the swamp area due to Jonglei Canal would be of the order of only $7 \%$, which could increase to $16 \%$ given the up-stream developments.
\end{abstract}

\section{Overview}

The swamp areas in the Nile Basin produce huge water losses in the order of tens of billions of cubic meters every year. These losses might be reduced through the realization of channelization projects, one of which is the Jonglei Canal project in the Sudd swamps in Southern Sudan. It connects the river Bahr el Jebel directly from Bor to Doleib Hill (close to Malakal, downstream of the Sudd region) as shown in Figure 1. Evaporation losses in the Sudd region are in the order of $20 \mathrm{~km}^{3}$ per year, as reported in several studies (e.g. Sutcliffe and Parks 1987). Construction work on the Jonglei project was begun in 1978. However the Southern Sudanese rebels brought the works to a halt in 1984. About 240 $\mathrm{km}$ of the canal of a total of $360 \mathrm{~km}$ had been excavated. The canal has been the subject of a lot of debate. The main benefits of the project as reported by several researchers (e.g. El-Moghraby and El-Sammani 1985; Howell et al. 1988) can be summarized as follows: save significant amounts of water lost to evaporation and transpiration; reduce the risk of flooding that regularly occurs in the neighbouring area of the Nile; increase the availability of grazing land; provide a navigation link between the three countries; provide an all-weather road along one bank of the canal; enhance trade between the three countries and provide job opportunities for local people; reduce the prevalence of disease vectors; and boost the lives of local people in the area of the project economically, socially and culturally by promoting development and increasing agricultural, livestock farming and industrial expansion.

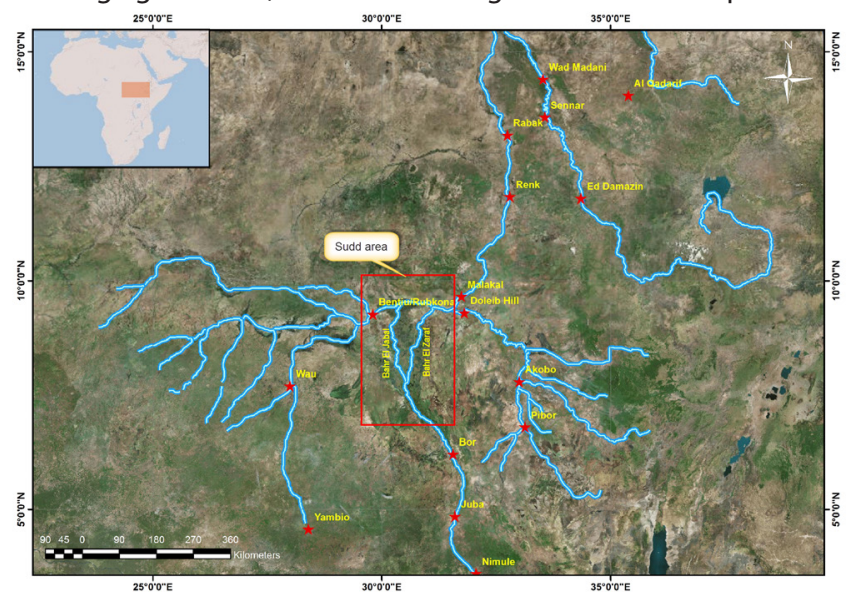

Figure 1 The Sudd swamp area.

On the other hand some other studies have identified environmental and social concerns over the project (e.g. Howell et al. 1988; Ahmad 2008). Their main concerns are: negative effects on flora and fauna in the Sudd region; increased conflict over pasture between tribes; the canal can become a barrier

Allam, Mariam M., Hesham M. Bekhit, Alaa M. Elzawahry and Mohamed N. Allam. 2018. Jonglei Canal Project Under Potential Developments in the Upper Nile States. Journal of Water Management Modeling 26:C448. https://doi.org/10.14796/JWMM.C448

(c) CHI 2018. www.chijournal.org ISSN 2292-6062. 
between villages; changing the paths of animal migrations; drop in groundwater levels; it may affect the hydrological system and reduce rainfall in the region; and it will affect water quality and sediment transportation.

In addition to the debate around Jonglei Canal, the Sudd swamps may also be affected by anticipated development in the upstream countries. The upstream countries in the Equatorial plateau are drawing up national development plans and policies to cope with the requirements of their citizens. Most of these development plans require additional extraction of water from the River Nile. With the implementation of these projects the flow to the river Bahr el Jebel in Southern Sudan will be reduced, and thus there will be a decrease in the water losses in the region and a decrease in the expected water savings from Jonglei Canal. The feasibility of the Jonglei Canal project needs to be reassessed in the light of these ambitious development plans. This research study aims to evaluate the technical feasibility of Jonglei Canal, and to determine to what extent the water losses can be reduced in the Sudd region without adversely impacting the environment. More specifically, the study will evaluate the environmental concerns that are in opposition to the project, and assess the impact of upstream development projects (if implemented) on the flow of the Nile in the Sudd region.

\section{Study Area}

The Sudd wetlands lie between latitudes $6.5^{\circ} \mathrm{N}$ and $9.5^{\circ} \mathrm{N}$ and longitudes $30.167^{\circ} \mathrm{E}$ and $31.75^{\circ} \mathrm{E}$. The Sudd wetland is $320 \mathrm{~km}$ wide by $400 \mathrm{~km}$ long. As the Nile River leaves the equatorial lakes and reaches a certain point in the Sudd area, it branches into two rivers, Bahr el Jebel and Bahr el Zaraf, as shown in Figure 1 above. The course of the river in the Sudd region is widened and the water overflows its banks and floods the adjacent lands, which are almost flat. The slope of the river and the adjacent area ranges between $8 \mathrm{~cm} / \mathrm{km}$ and $10 \mathrm{~cm} / \mathrm{km}$, creating a vast marshland. The Sudd region receives a total annual rainfall of $600 \mathrm{~mm}$ to $700 \mathrm{~mm}$ in the northern parts and increases to $800 \mathrm{~mm}$ to 1000 $\mathrm{mm}$ in the south. The total area of the Sudd covers $8000 \mathrm{~km}^{2}$. The region around Jonglei Canal is called the Sudd region because of the thick layer of floating vegetation that covers the area. This vegetation hampers navigation and can absorb or dissipate more than half of the water it receives. Thus any substantial increase in flow at the head of the swamps does not result in a directly proportional increase in discharge at the tail of the swamps. This is attributed to an associated increase in evapotranspiration losses as shown by the historical records given in Table 1 .

Table 1 The mean annual percentage of water losses for different time periods.

\begin{tabular}{cccc}
\hline Period of time & $\begin{array}{c}\text { Average flow measured at Mongalla } \\
\text { (entrance to swamp), } \mathrm{km}^{3}\end{array}$ & $\begin{array}{c}\text { Average flow measured } \\
\text { at swamp exit, } \mathrm{km}^{3}\end{array}$ & Percentage losses \\
\hline $1905-1960$ & 26.8 & 14.2 & 47 \\
$1905-1980$ & 33 & 16.1 & 51.2 \\
$1961-1980$ & 50.3 & 21.4 & 57.5 \\
\hline
\end{tabular}

The canal extends between Jonglei and the mouth of the Sobat River as shown in Figure 2. Jonglei Canal was designed to bypass the Sudd and route a proportion of the water lost from the Nile River by spill and evaporation in the swamps. The canal was planned in two phases. The first phase of the project included the digging of a canal to convey approximately $4.8 \mathrm{~km}^{3}$ of water annually to the affected countries (i.e. Egypt, Sudan and South Sudan). In the second phase the discharge is to be increased by $3.5 \mathrm{~km}^{3}$. The canal has a trapezoidal cross section with bottom width $30 \mathrm{~m}$.

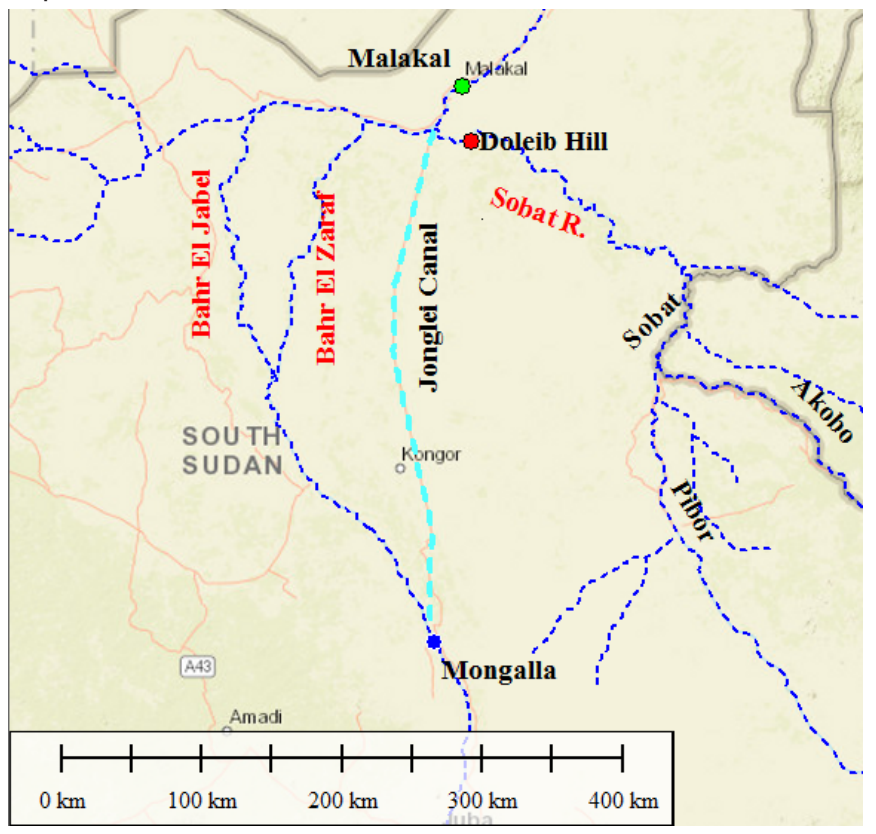

Figure 2 Map of the Sudd region showing the route of Jonglei Canal.

Modeling the Sudd region has received attention from several researchers. Sutcliffe and Parks (1987) modeled the water balance of the Sudd region. Their water balance model is represented by a hydrological model, in which they used the measured inflows to the Sudd and the measured outflows together with estimated values of rainfall and evaporation. The model output was a simulation of volumes and areas of flooding over the historical period 1905-1980. Their study presented the effects of the Jonglei Canal project on the flooding areas. The study concluded that an average reduction in seasonal swamp areas of $11 \%$ to $32 \%$ may be expected. Tahir (1980) investigated several objections raised by environmentalists regarding the Jonglei Canal project. He found that the reduction in wetland area that may be caused by the operation of the canal is around $10 \%$, with no real effect on the rainfall in the region. He concluded that the canal will have minor effects on grazing activities, as the expected fluctuations in the swamp's water levels can be mitigated by providing crossing points and water points for cattle and people. It was also found that no depletion will occur in the groundwater of the Nubian sandstone aquifer underlying the study area. Tahir (1980) found that the canal will improve economic and social life and provide irrigation water, flood control and a waterway for 
navigation purposes. Lamberts (2009) studied, through a water balance model, the effects of Jonglei Canal operation on the Sudd swamps. Lambert studied different operation scenarios that included a fixed canal flow and a seasonal dependent canal flow. The study concluded that any change in the permanent swamp area depends on the total yearly flow, while change in the seasonal swamp area depends on the volume of canal flow in the wet period. Although the abovementioned models gave general ideas about the different water budget components of the Sudd region, the studies lack any comprehensive analysis of the hydrodynamics of the Sudd swamps that can account for the variation in flood plains under both anticipated developments in upstream countries and the operation of Jonglei Canal. Our research tries to bridge this gap by developing a hydrodynamic model of the Sudd region using surveyed cross section data.

\section{Methods and Procedures}

The main objective of this study is to get insight into the consequences of changing the area of the swamp due to the combined effects of Jonglei Canal and different scenarios of water use development in the equatorial countries. Accordingly, the effect of Jonglei Canal will be evaluated for each scenario. Figure 3 gives the general framework of the methodology we followed to achieve the research objective.
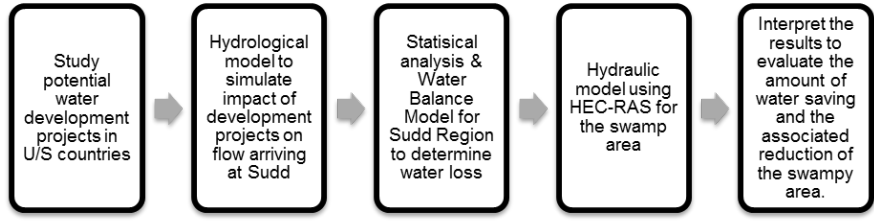

Figure 3 Flowchart of the proposed methodology.

We adopted the following procedures:

1. Study and analyze the potential water development projects in the equatorial plateau countries to determine the current and future potential development and the associated water requirements. This task is ccomplished by analysis of the data in the national master plans of these countries and the documentation of the Nile Basin Initiative. The analysis leads to predictions of future development scenarios.

2. Carry out a hydrological model of the entire Nile basin system to simulate the impacts of development projects and associated scenarios on the Nile River flow arriving at Bahr el Jebel (the entrance to the swamp area). The hydrological modeling is done with the Nile decision support tool (Nile DST).

3. After obtaining the simulated flow entering Bahr el Jabel from the hydrological model, the flow values are imported into a newly developed mass balance model for the Sudd region. This model is developed by establishing a regression relationship between the flow entering Bahr el Jebel (the Sudd region) and the water losses from the swampy area of the Sudd region using historical flow data. The main objective in using the mass balance model is to determine the effect of the resultant variation in the Nile River flow entering Bahr el Jebel on the flow of the Nile River at Malakal (the outlet of the swamp area).

4. Construct a hydraulic model for the swamp area using HEC-RAS to determine the combined effect on the area of the swamp of both Jonglei Canal and water abstraction due to upstream development projects.

5. Interpret the results in order to evaluate the amount of water saving and the associated reduction in the area of the the swamp.

\subsection{Assessment of Water Requirements for Future Upstream Development Projects}

We acquired all the documentation and data associated with the recent studies of the Nile Basin Initiative regarding water development projects in the Upper Nile countries and reviewed the national plans of the Upper Nile countries. We extracted the data we required from this documentation. We found that several agricultural development projects have been proposed in Uganda, Kenya, Tanzania, Ruanda and Burundi (see Figure 4).

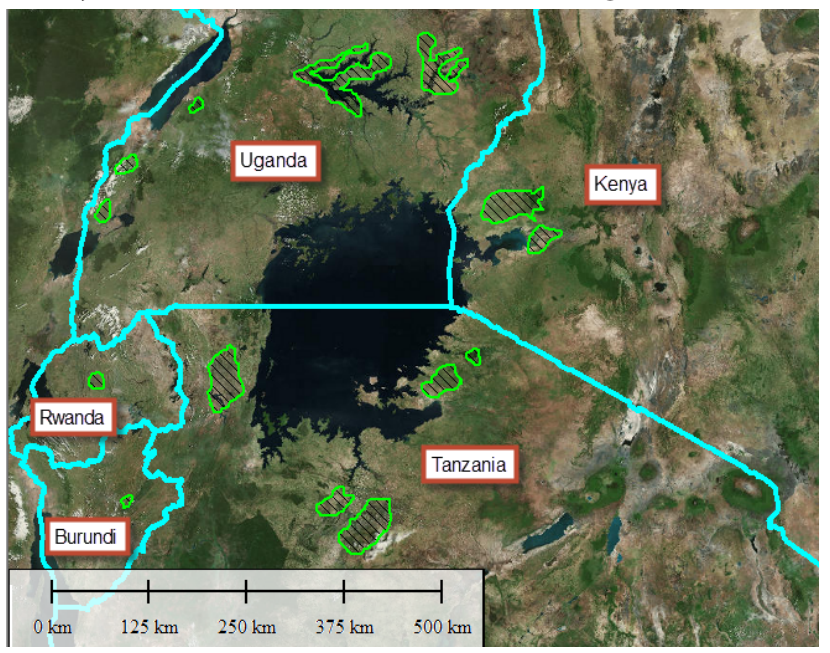

Figure 4 Upstream countries development projects.

The data collected from different countries, which have different horizons for development, vary widely. Thus only the most feasible development projects were considered in the first stage of development. Different scenarios for developments will be assessed to cover the variability of these projects. Figure 4 shows the locations of the most feasible development projects in the upstream equatorial countries, highlighted in hatched polygons. All the projects are located in the vicinity of Lake Victoria and its tributaries. Accordingly, in the hydrological simulation of these abstractions, the water requirements for these projects will be taken from Lake Victoria. 
The crop water requirements for the different agricultural development projects were estimated based on soil, climate and crop data and are shown in Table 2, which summarizes the proposed development projects for these countries and the corresponding water requirements. These water requirements will be simulated in the hydrological modeling as direct abstraction from Lake Victoria. The hydrological modeling also considers the seasonality of these water requirements as well as irrigation scheduling requirements. Upstream agricultural development projects are assumed to be irrigated only during the dry seasons since the irrigation system used is supplementary irrigation.

Table 2 Development projects proposed by the Upper Nile countries that are likely to occur.

\begin{tabular}{lccc}
\hline \multicolumn{1}{c}{ Country } & Project & $\begin{array}{c}\text { Development Projects } \\
\text { (thousands ha) }\end{array}$ & Water Requirement $\left(\mathrm{km}^{3} / \mathrm{y}\right)$ \\
\hline Uganda & Agricultural & 184.8 & 1.6 \\
Kenya & Agricultural & 262.5 & 1.9 \\
Tanzania & Agricultural & 346.1 & 2.65 \\
Ruanda \& Burundi & Agricultural & 14.7 & 0.1 \\
$\quad$ Total & & & 6.25 \\
\hline
\end{tabular}

To account for future developments and their uncertainty in the upstream countries, three development scenarios were considered. Scenario A presents the most likely future scenario, which assumes a total annual water requirement of $6.25 \mathrm{~km}^{3}$ extracted from Lake Victoria, as shown in Table 2. Scenario B assumes that all planned development projects are increased by $50 \%$, and the corresponding annual abstraction from Lake Victoria is assumed to be $10 \mathrm{~km}^{3}$. Scenario $C$ assumes an increase in the annual total water requirements of the development projects of $100 \%$ and the corresponding annual abstraction from Lake Victoria is assumed to be $13 \mathrm{~km}^{3}$.

\subsection{Hydrologic Simulations Using Nile DST}

Nile DST is software that was developed by the Georgia Water Resources Institute at Georgia Tech in collaboration with the Nile countries focal point institutions as a product of the Nile Basin water resources project. The Nile DST is an integrated software package with three major components: database, interface, and application modules (Georgakakos 2002). Nile DST was developed as a tool for assessing proposed water development and management options in the Nile basin and their effects on the current situation and consequences for the water users. The Nile DST application modules contain applications for various purposes. The modules are are Database, Data Analysis Tool, Hydrology, Agricultural Planning, Remote Sensing, and River Simulation and Management. The River Simulation and Management module time resolution is $10 \mathrm{~d}$. Nile DST includes a routing model for each river reach and regulation rules for each reservoir.

Nile DST had been successfully used to simulate the Nile river system in several studies. For example, Tidwell (2006) used Nile DST in an assessment of the impacts of climate change on water resources in the Nile River basin. In this study climate and hydrologic assessments were inputs to the Nile DST model, which was used to determine the impacts of climate on water resources planning and management in the Nile River basin. The study concluded that water supply deficits will emerge by 2030 and will continue to increase in frequency and magnitude to 2080 . Ezzo (2007) used Nile DST to compare the formal regulatory rules of the Owen Falls dam with the current rules on Lake Victoria. The study showed that increasing the lake release by $30 \%$ will drop the lake level to a minimum and cause a complete halt in hydroelectric generation, while a release of $10 \%$ over the baseline regulation rule will lead to a total failure in the operating protocols of the Owen Falls dam. The study also showed that there will be negligible effects on High Aswan Dam average water levels and hydroelectric generation but that opening Jonglei Canal will increase High Aswan Dam storage and hydroelectric generation.

\subsection{Statistical Analysis for the Sudd Region}

We developed a local mass balance model for the Sudd region to accurately estimate the hydraulic changes and the associated evapotranspiration losses in the region due to Jonglei Canal flow. The mass balance model relies on the historical records to establish a regression equation between the incoming flow and the water losses inside the Sudd region. Flow data were obtained from the Nile Water sector of the Ministry of Water Resources and Irrigation in Egypt for three stations, Mongalla, Malakal and Doleib Hill. The data from these three stations are essential in calculating the water budget components inside the Sudd region; Mongalla station gives the recorded inflow upstream of the Sudd region, Malakal station gives the outflow downstream of the Sudd region, and Doleib Hill station gives the inflow to the Sobat River. The water arriving downstream of the Sudd is a contribution of two main tributaries, Bahr el Jabel and the Sobat River. The difference between the measured flows at Malakal station and Doleib Hill station gives the contribution of the Sudd region to the White Nile upstream of Jonglei Canal (see Figure 2 above). The data from the three stations extends from 1913 to 2006 in 10 d intervals. A sample of monthly flow data measured at the three stations is shown in Figure 5, which shows that there was a jump in the flow values of Mongalla and Malakal stations that occurred in the early 1960s. The increase occurred because the level of Lake Victoria rose in the period 1961-1964. This jump did not appear in Doleib Hill station as it receives water from another catchment.

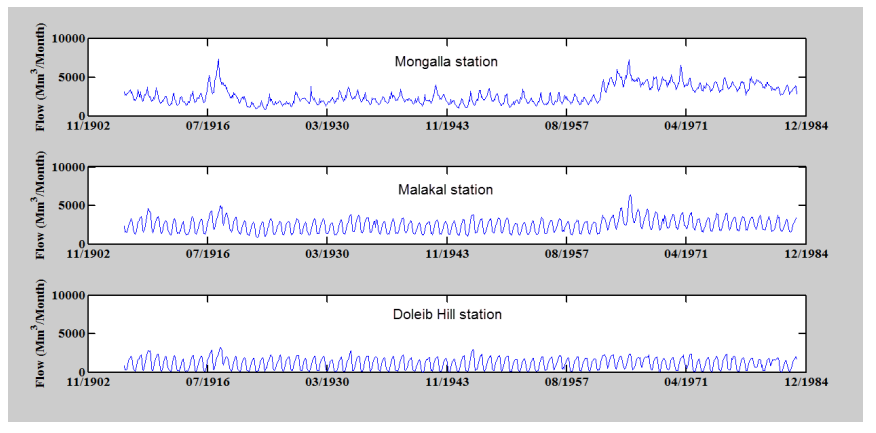

Figure 5 Monthly flow data observed at Mongalla, Malakal and Doleib Hill stations. 
To test the relationships between the flow time series measured at the three stations, cross correlation was used. Figure 6 shows the cross correlation between the three stations. Cross correlation, which defines the time-lagged interrelation of two datasets, is necessary to measure the strength and direction of correlation between two time series.

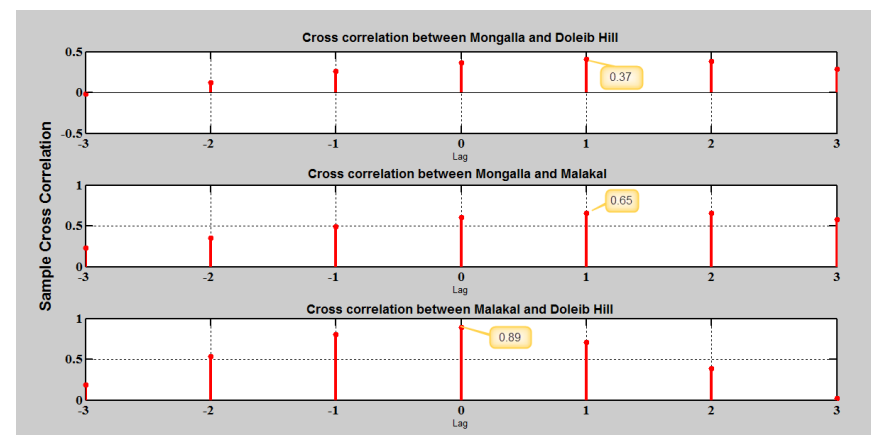

Figure 6 Cross correlation between monthly flow data time series observed at Mongalla, Malakal and Doleib Hill stations.

Figure 7 shows the correlation matrix between the three stations at the lag corresponding to the highest correlation. Figure 7 shows histograms of the average monthly flow along the matrix diagonal to examine the trend of the flow and to determine the wet and dry periods throughout the year for each station. Scatter plots for each pair of stations appear off diagonal, where the slopes of the reference lines in the scatter plots are equal to the displayed correlation coefficients. The relationship between Mongalla and Doleib Hill shows that the corresponding data have a random pattern indicating a very poor correlation between the two stations (0.37). The reason for the low correlation is that the two stations are measuring two different catchments. The flow at Mongalla originates from the equatorial plateau while the flow at Doleib Hill is from the Sobat River. It is evident that the average flow patterns in the two stations are different. It can be deduced from the two plots of the flow pattern that the wet period for Mongalla station occurs around August whereas for Doleib Hill it occurs around October. On the other hand no clear dry period is observed for Mongalla whereas Doleib Hill has a dry period in March and April.

Figure 7 shows a strong relation between the two flow series for Mongalla and Malakal. The correlation diagram shows that there tends to be a linear relationship, with a correlation coefficient 0.65 . The flow patterns of the two stations are similar. Finally, the correlation diagram between Doleib Hill and Malakal shows a tendency for a strong linear relationship with a correlation coefficient 0.89 .

As mentioned earlier, the flow at the exit of the swamp area (the contribution of the Bahr el Jebel swamps to the flow measured at Malakal) can be computed by subtracting the flow measured at Doleib Hill from the flow measured at Malakal. The losses at the swamp area are then computed by subtracting the flow exiting the swamp area, obtained above, from the flow entering the swamp area, which is measured at Mongalla station. The average
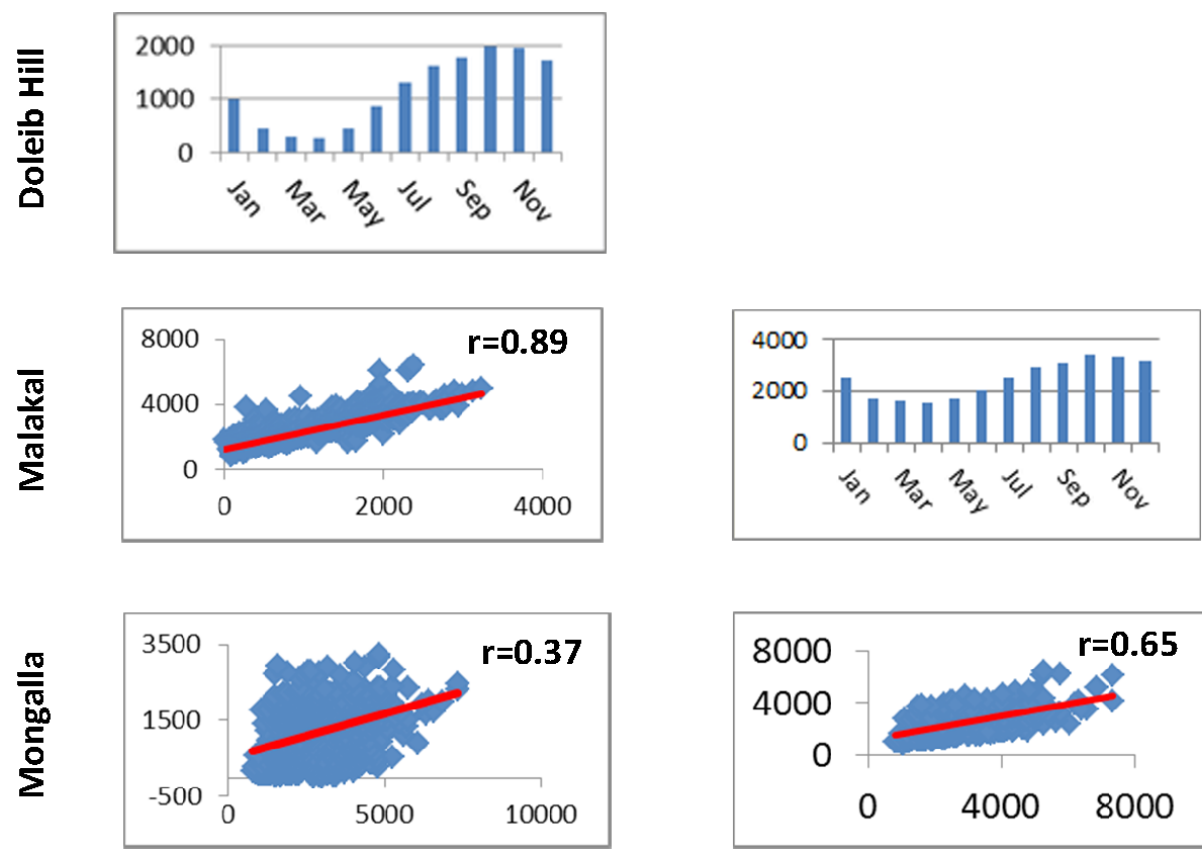

Doleib Hill

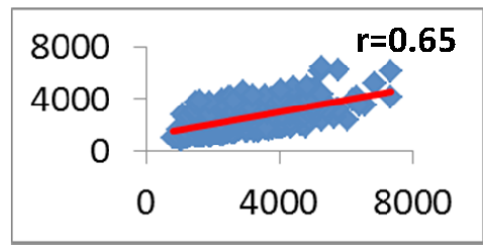

Malakal

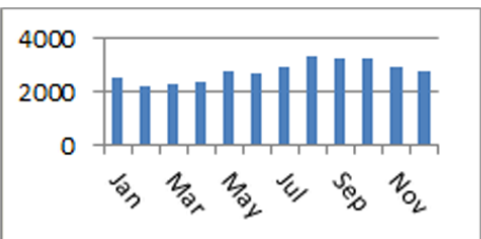

Mongalla

Figure 7 Correlation matrix plots between monthly flow data time series observed at Mongalla, Malakal and Doleib Hill stations. 
monthly loss through the Bahr el Jebel swamps was then calculated and plotted as shown in Figure 8, which shows that the flow pattern of water losses in the swamp is consistent with the flow pattern measured at Mongalla (Figure 7). For example, the maximum losses in the swamp occurred around August and the minimum losses occurred in February, which are highly correlated with the maximum and minimum flows reaching the entrance of the swamp at Mongalla station.

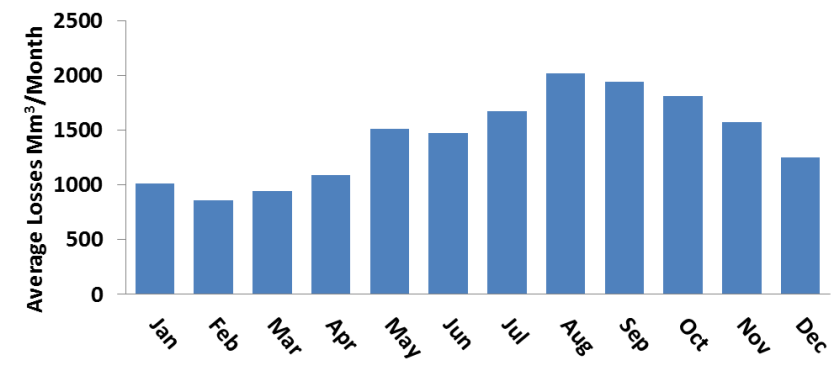

Figure 8 Monthly average losses through Bahr el Jebel swamps.

A linear regression is shown between the losses in the swamp area and the flow at Mongalla. Several diagnostic statistics were obtained for this relationship. These were the coefficient of determination $\left(R^{2}=0.945\right)$, the root mean square error (RMSE $=$ 181.7), and the F-test (= 1290.8).

\subsection{Hydraulic Modeling for the Sudd Region}

The HEC-RAS model simulates the resulting flow from the Nile DST model through Jonglei Canal and Bahr el Jebel and analyzes the existing Jonglei Canal cross section to evaluate the effect of both Jonglei Canal and the development projects on the swamps. The hydraulic model is developed using the cross sectional data available for Bahr el Jebel and Jonglei Canal.

\section{Results and Discussions}

\subsection{Results of Hydrological Simulation Under Different Development Scenarios}

As described earlier, three scenarios were considered for upstream development. The Nile DST model was used to determine the variation in the flow of the Nile River at Mongalla (upstream of Jonglei Canal) that would result from the upstream development scenarios. Figure 9 shows the simulated flow at Mongalla, which clearly indicates a significant decrease in the flow for the different scenarios, especially in the dry seasons. As seen in Figure 9 the average deficit in the flow arriving Mongalla was found to be 3.60 $\mathrm{km}^{3} / \mathrm{y}, 5.40 \mathrm{~km}^{3} / \mathrm{y}$ and $6.70 \mathrm{~km}^{3} / \mathrm{y}$ for development scenarios A, B and $C$ respectively. In the case of the dry seasons, Figure 9 shows that the maximum deficit in the flow arriving Mongalla was 6.07 $\mathrm{km}^{3} / \mathrm{y}, 7.97 \mathrm{~km}^{3} / \mathrm{y}$ and $9.28 \mathrm{~km}^{3} / \mathrm{y}$ for development scenarios A, B and $C$ respectively.

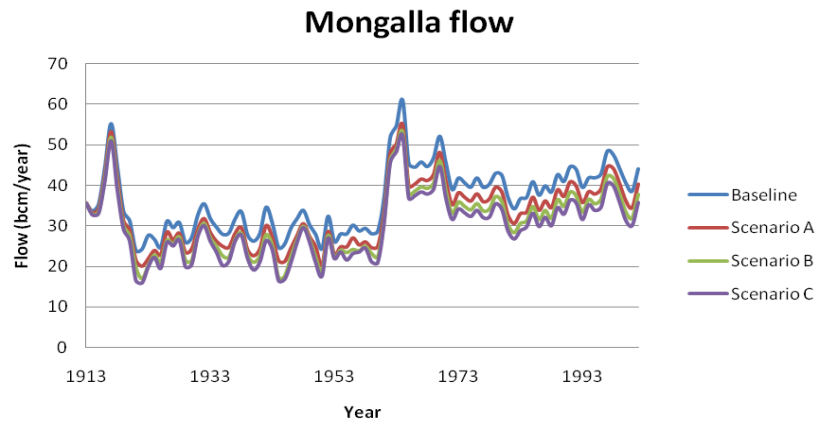

Figure 9 Simulated flow at Mongalla for the different development scenarios.

The technical feasibility of the Jonglei Canal project may be determined by whether the canal can reliably produce the planned annual water savings (i.e. reduction in water lost through evapotranspiration in the swamps) of $4.8 \mathrm{~km}^{3}$ for the first phase and $7 \mathrm{~km}^{3}$ for the second phase. The reliability of the canal is computed as the percentage of the years of success to achieve the required water saving target. To calculate the reliability of Jonglei Canal after the completion of the upstream development, the water losses inside the swamps were calculated. The losses through the Sudd swamps that correspond to the simulated annual Mongalla flow time series (Figure 9) were calculated using the statistical mass balance model that we developed. The losses through the Sudd swamp area were then compared to the planned water savings given by Jonglei Canal. If the losses within the swamps exceed the planned water diversion through Jonglei Canal then the canal project will be considered reliable. On the other hand, if the losses within the swamps are found to be less than the expected water diversion by Jonglei Canal in any year then a failure occurs in that year and Jonglei Canal will be considered as non-reliable in achieving its water savings for this year. The reliability calculation in this case is based on the water availability only, without considering any negative impacts (which will be assessed through hydraulic modeling) on the Sudd swamps. Figure 10 shows the reliability of Jonglei Canal with its two phases for the different scenarios.

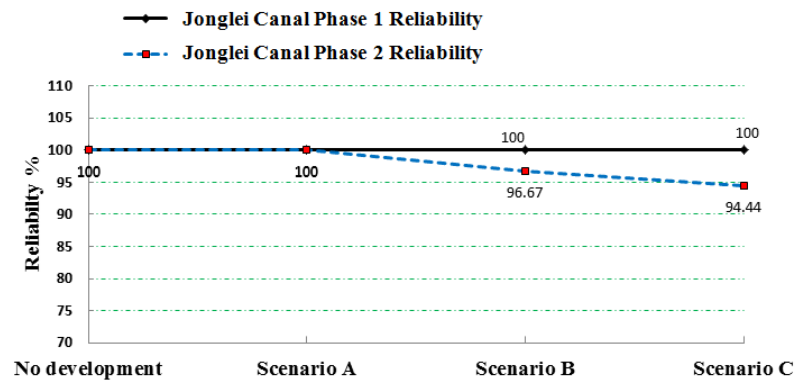

Figure 10 The variation of Jonglei Canal reliability for the different upstream development scenarios.

For the first phase of the canal $\left(4.8 \mathrm{~km}^{3}\right.$ annual saving), Jonglei Canal was found to be perfectly reliable in covering 
the planned water savings for all the development scenarios. However, for the second phase the reliability of Jonglei Canal decreased for the development scenarios B and C to be $96.67 \%$ and $94.44 \%$ respectively. A reliability of $94.44 \%$ means that in 100 $y$ there will occur only 6 failures (i.e. years in which Jonglei Canal will not be able to divert the planned water saving quantity).

Sensitivity analysis was carried out using the Nile DST model to estimate the effect of a unit withdrawal from Mongalla on the flow reaching the White Nile at Malakal. This sensitivity analysis is used to estimate the average flows arriving at Malakal for the different development scenarios. Figure 13 shows the average White Nile flow for the different development scenarios. The variation in the average White Nile flow (after the Sudd swamp) was obtained for the different development scenarios based on Jonglei Canal operation phases by adding the flow at the exit of the swamp to the water saving of the Jonglei Canal project. It is evident from Figure 13 that Jonglei Canal is crucial for compensating downstream countries for the water shortage that will result from the upstream developments.

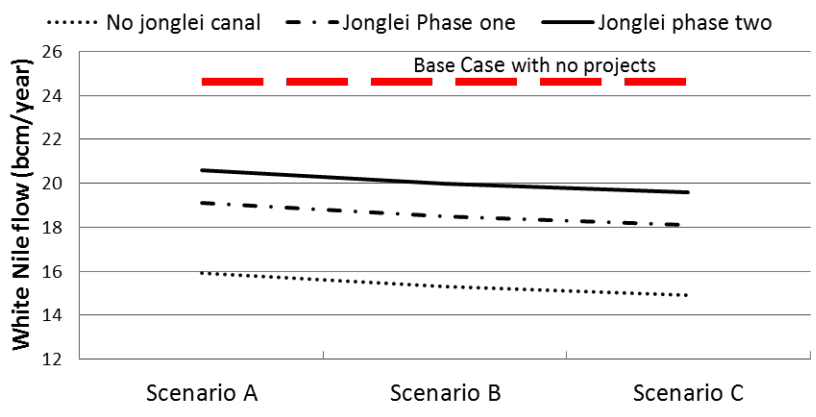

Figure 11 Variation of the average White Nile flows for the different scenarios.

\subsection{Results of Hydraulic Simulation under Differ- ent Development Scenarios}

Two HEC-RAS models were developed for the study area: one model for Bahr el Jebel and its swamps before the construction of Jonglei Canal and the second model for after the construction of Jonglei Canal. The models were developed using the cross sectional data available for Bahr el Jebel and for Jonglei Canal (Allam 2011). Several hydraulic simulations were performed including a baseline scenario. The simulation scenarios include:

1. Baseline: Using the actual swamp area and the original historical flow time series at Mongalla to obtain the swamp size.

2. Upstream development without Jonglei Canal: To assess the effects of the upstream development projects in the equatorial plateau on the size of the swamp area.

3. Jonglei Canal with no control structures: This scenario assumes that there are no gates at the entrance of Jonglei Canal to control the flow and that the flow is divided between Bahr el Jebel and Jonglei Canal, determined by the hydraulic conditions of each stream. This scenario is divided into two categories: the first with the upstream development and the second without the upstream development.

4. Jonglei Canal with control structures: This scenario assumes there is a control structure upstream of Jonglei Canal to route the required flow to Jonglei Canal before routing flow to Bahr el Jebel. This scenario is divided into the same two categories as the preceding one, using historical flow data and the simulated flow data.

The above simulations were carried out using five representative values for the flow to represent the five different seasons of flow. The five values were determined as follows:

- Very Wet: the largest value of annual flow from the historical flow data;

- Average Wet: the 75th percentile value of flow from the historical flow data;

- Average: the 50th percentile value of flow from the historical flow data;

- Average Dry: the 25th percentile value of flow from the historical flow data; and

- Very Dry: the lowest value of annual flow from the historical flow data.

The effect on the swamp is calculated using the percentage reduction in the swamp size that was obtained from the hydraulic simulations.

The main reason for running the case of Jonglei Canal without a control structure at the canal entrance is to test whether the proposed cross section of Jonglei Canal under natural conditions will be sufficient to allow the required flow without the need to control the flow at the canal entrance. The results show that without the control the canal may be adequate during the first phase of the Jonglei Canal project, where the planned annual water saving is $4.8 \mathrm{~km}^{3}$. However, control structures must be introduced in the second phase otherwise the average annual flow of Jonglei Canal in the second phase will be around $5 \mathrm{~km}^{3}$ (i.e. $2 \mathrm{~km}^{3}$ less than the desired flow).

Figure 12 shows the impacts of Jonglei Canal and development scenarios on the size of the Sudd swamp compared to the base case. As shown in Figure 12, the examined hydraulic simulations are shown on the $x$-axis, and the reductions of the swamp size for each of the five representative values of flow are shown on the $y$-axis. It is evident from Figure 12 that the operation of Jonglei Canal will in itself will have only a minor effect in reducing the swamp area. The reduction in the swamp area for all but very low flows will be $<5.8 \%$ in phase 1 of the Jonglei Canal project and it may increase to $6.7 \%$ in the case of very low flow. This means that for most of the time the canal will have very little effect on the swamp. This reduction may increase to $6 \%-9.6 \%$ if the second phase of the Jonglei Canal project is implemented. 


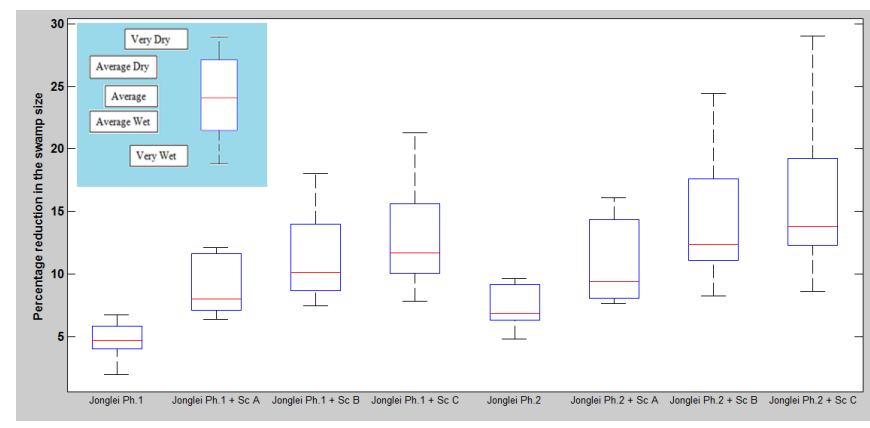

Figure 12 Percentage of reduction in the swamp area under different hydraulic simulations.

The results also show that under development scenario $A$, the reduction in the swamp area will be in the range $7 \%-16 \%$ in the most severe case. The reduction in the swamp area will increase to $8 \%-25 \%$ under development scenario B. The results for scenario $C$ are slightly higher than for scenario $B$ as the reduction in the swamp area will increase to $8 \%-30 \%$. It is evident from Figure 12 that increasing the upstream development beyond scenario A will lead to a significant reduction in the swamp area, which could be as much as $25 \%$ in scenario B and $30 \%$ in scenario $C$. These negative impacts may likely limit the upstream water abtraction to scenario $A$ to reduce the negative impact on the swamp area.

It is quite clear from the results of the previous simulations that the upstream development projects will lead to significant reductions in the area of the swamp if Jonglei Canal is in operation. The decrease in the swamp area could be lessened by distributing the reduced flows caused by the upstream development projects between Jonglei Canal and the swamp. This alternative could be a win-win situation where the reduction in the area of the swamp will be attenuated by some of the reduced flow entering Jonglei Canal, but this would lower the canal's reliability. This alternative would contribute to the integrated water resource management of the Nile River, which has to satisfy the development requirements of the entire basin while conserving the swamp. The reduced flow could be distributed between the swamp and Jonglei Canal using a pro-rated distribution between Jonglei Canal and Bahr el Jabal based on the relative cross section capacity of the two streams. Implementing this alternative will reduce the maximum decrease in the swamp area for the extreme case (the Very Dry condition) from $16.1 \%$ to $11 \%$ in the case of Scenario A + Jonglei Canal; from $25 \%$ to $15 \%$ in the case of Scenario $B+$ Jonglei Canal; and from $30 \%$ to $17 \%$ in the case of Scenario $C+$ Jonglei Canal. At the same time the minimum reliability of Jonglei Canal will range from $90 \%$ to $72 \%$ depending on which development scenario occurs.

\section{Conclusions}

We reassessed the feasibility of the Jonglei Canal project under new upstream development plans. Results show that the development projects in the Upper Nile Basin countries in the basins of the equatorial lakes will cause an annual reduction in the Nile River average flow at Mongalla in the order of $3.6 \mathrm{~km}^{3}$ to $6.7 \mathrm{~km}^{3}$, or $10 \%-20 \%$, for different development scenarios. This makes it vital that there are water saving projects that compensate for these shortages. The first phase of the Jonglei Canal project will increase annual average flow at Aswan by 3\%, and this increase will lessen to $1 \%-2 \%$ if the upstream development projects take place. If Jonglei Canal is constructed in its two planned phases, the Nile River annual average flow at Aswan will increase by $\sim 4 \%$, but it will be only $2.5 \%-3 \%$ if the upstream development projects are implemented. The results show that for Jonglei Canal construction with development scenario $A$, the reduction in the swamp area will be in the order of $7 \%-16 \%$. This increases to $8 \%-25 \%$ under development scenario B, and increases to $8 \%-30 \%$ under development scenario C. We presented an alternative that may lead to a win-win situation of all the upstream and downstream development happening but with the swamp environment being conserved. This alternative is based on partially satisfying the demand during dry years to conserve the swamp environment and fully satisfying the demand during wet years. With the suggested alternative the negative impacts could be reduced by $>38 \%$ on average.

\section{References}

Ahmad, A. M. 2008. “Post-Jonglei Planning in Southern Sudan: Combining Environment with Development." Environment and Urbanization 20 (2): 575-86. https://doi.org/10.1177/0956247808096129

Allam, M. M. 2011. Hydrologic and Hydraulic Study of Jonglei Canal Project Under the Potential Development Schemes in the Upper Nile Countries. Cairo: Cairo University. Master's thesis.

El Moghraby, A. I. and M. O. el Sammani. 1985. "On the Environmental and Socio-economic Impact of the Jonglei Canal Project, Southern Sudan." Journal of Environmental Conservation 12 (1): 41-8. https://doi.org/10.1017/S0376892900015149

Ezzo, H. Y. 2007. Effects of Applying New Operational Rules for Owen Dam on Lake Nasser Inflow. Cairo: Cairo University. MSc thesis.

Georgakakos, A. P., M. Andgelic and K. P. Georgakakos. 2002. "A Decision Support System for Lake Victoria." In Proceedings of the 6th Nile 2002 Conference, Kigali, Rwanda, February 23-27, 2002.

Howell, P., M. Lock and S. Cobb. 1988. The Jonglei Canal: Impact and Opportunity. Cambridge: Cambridge University Press.

Lamberts, E. 2009. The Effects of Jonglei Canal Operation Scenarios on the Sudd Swamps in Southern Sudan. Twente: Twente University. MSc thesis.

http://essay.utwente.nl/59163/1/scriptie_E_Lamberts.pdf 
Sutcliffe, J. V. and Y. P. Parks. 1987. "Hydrological modeling of the Sudd and Jonglei Canal." Hydrological Sciences Journal 32 (2): 143-59.

https://doi.org/10.1080/02626668709491174

Tahir, A. A. 1980. "The Sudd as a Wetland Ecosystem and the Jonglei Canal Project." Water Supply and Management 4 (1/2): 53-4.
Tidwell, A. C. 2006. Assessing the Impacts of Climate Change on River Basin Management: A New Method with Application to the Nile River. Atlanta, GA: Georgia Institute of Technology. PhD dissertation.

https://smartech.gatech.edu/bitstream/handle/1853/.../tidwell_amy_c_200612_phd.pdf 